\title{
UJI GETAH DAUN BITADIN DALAM MENYEMBUHKAN LUKA PADA KULIT
}

\author{
Ilham Malindo Putra*1 \\ ${ }^{1}$ Pendidikan Kimia,FMIPA,Universitas Negeri Padang, Indonesia \\ *Email: ilhammalindoputra1999@gmail.com
}

\begin{abstract}
ABSTRAK : Studi ini bertujuan untuk membuat getah daun bitadin yang digunakan untuk mengobati luka yang terjadi pada kulit. Metode yang dilakukan adalah eksperimen dan uji aktifitas katalik secara lansung. Tahapan pertama dilakukan dengan pembuatan getah daun bitadin. Uji aktifitas lansung dilakukan dengan variasi tetesan-tetesan getah yang ditetesi kepada kulit yang terluka. Proses penyembuhan lebih kurang 2 hari untuk proses pengeringan. Untuk sembuh total diperkirakan selama 5 hari tergantung lebar luka pada kulit. Dipakai cukup 1 kali saja bagi luka dengan kondisi yang ringan. Bagi luka yang lumayan lebar pemakaian dalam 1 hari 2 kali pemakaian. Hasil dari eksperimen membuktikan bahwa getah daun bitadin dapat menyembuhkan luka. Kondisi optinum getah iyalah menyembuhkan luka tercapai pada (2-6 )hari penyembuhan ini diduga karna aktivitas katalik getah daun bitadin terhadap luka yang dialami.
\end{abstract}

Kata kunci: getah tanaman bitadin,antioksidan,

\section{PENDAHULUAN}

Reaksi kimia sangat banyak ditemukan dalam kehidupan sehari-hari sesuatu yang ada di dunia ini tidak terlepas dari adanya reaksi - reaksi kimia. Untuk itu kita perlu mengetahui apa itu reaksi kimia. Dengan kita tahu apa itu rekasi kimia kita akan mudah memahami apa-apa saja kandungan - kandungan yang ada di dunia ini.jika kita tidak memehami apa saja manfaat dari mengetahui reaksi kimia kita akan mudah terjerumus ke dalam kehidupan yang membuat kita dalam keadaan yang berbahaya[1][2]. Salah satnya dengan adanya reaksi kimia kita dapat untuk mengetahui baik atau buruknya apa yang di konsumsi dalam tubuh mahluk hidup. Dan dengan adanya reaksi-reaksi kimia banyak para ilmuwan dapat memunculkan konsep-konsep yang baik yang sangat dibutuhkan oleh tubuh sehingga dapat mencegah sebuah penyakit atau sebagai antibiotik.[3]

Dengan mempelajari reaksi kimia kita juga dapat mengubah presepsi masyarakat yang mengtakan kimia sangat penuh dengan hal-hal yang berbahaya menjadi ilmu yang sangat berguna bagi mereka . dengan blajar reaksi kimia kita juga dapat membagikan ilmu buat saudara- saudara kita dengan mengajarkan begitu banyaknya reaksi kimia yang berguna bagi kehidupan[4][5]. Kita dapat mengugatkan makanan yang dikonsumsi baik atau tidaknya bagi tubuh mahluk hidup. Kita juga 
dapat memanfaatka pengetahuan ini untuk menolong saudara-saudara kita yang tidak bisa mengobati diri ke rumah sakit karena biaya dengann membuat obat -obatan debngan bahan-bahan alam yang kita sudah ketaui apa saja unsur yang ada di dalamnya.[7] Yang bana pengobatan itu memudahkan saat proses pembuatannya salah satunya pengobatn uka pafda kulit dengan memanfaatkan getah bitadin. Sebelumnya kita harus tau tahap -tahap setra kandungan dari proses pemanfaatan getah tersebut.[8]

Dalam berbagai ilmu pengetahuan pun tak lepas dengan adanya reaksi-reaksi kimia diantaranyadalam ilmu biologi,fisika,matematika dan lain-lain dari masingmasing pelajaran itu ada kaitan erat dengan reaksi kimia. Salah satu contoh dalam melihat adanya suatu reaksi kimia iyalah pada proses pembusukan[9][10] . yang mana objek yang kita gunakan iyalah buah apel yang sebelumnya sudah digigit lalu kita biarkan di lingkungan teerbuka lama kelamaan warna bekas gigitan akan berubah warna. Dari perubahan warna itu menunjkan adnya eaksi-reaksi kimia. Masih banyak lagi contoh dari pembuktian adanya eaksi-reaksi kimia. Jadi antara reaksi kimia dengan kehidupan sangatlah memiliki hubungan yang erat bagi mahluk hidup.[11]

Raksi kimia juga banyak di gunakan dalam banyak bidang diantaranya dalam bidang pengobatan dan penybuhan salah satunya iyalah pemanfaataan getah daun bitadin. Daun bitadin sangat banyak kita temui di lingkungan sekitar apalagi di perkampungan . orang - orang terdahulu sangat banyak menanam tanaman ini karna sangat bermanfaat dan dalam penggunaannya pun juga praktis dan mudah[12][13]. Pada tanaman tumbuhan bitadin ini yaang sering d gunakan ialah terletak pada getah dari tumbuhan itu. [14]Karna dapat menyembuhkan luka yang di alami pada kulit. Tumbuhan ini daunnya hampir mirip dengan daun ubi akan tetapi bentuk daunnya berbeda. Banyak masyarakan menggunakan tumbuhn ini untuk menyembukan luka. Getah dari daun ini tidak berbau, dengan warna agak kekuningan, bentuk cairannya pun tidak kental. Tumbuhan bitadin ini sangat mudah di tanam di lingkungan salah satunya di indonesia.[15][16]

Daun bitadin itu sendiri di daerah pasaman barat sangat banyak di jumpai kebannyakan tumbuhan ini tumbuh di perkarangan-perkarangan rumah[17]. Jadi kebannyakan masyarakat di sana jika terjadi luka pada kulit biasanya bagi yang di lingkungannya ada tumbuhan bitadin biasanya mereka menggunakan getah dari dan bitadin sebagai pertolongan pertama[18][19]. Biasanya getah dari daun ini jika luka ringan hanya cukup diteteskan saja dan dibiarkan beberapa hari hingga luka mengering. Biasanya luka saat ditetesi oleh getah daun bitadin ini akan terasa perih. Di karenakan berkerjanya unsur-unsur daun terhadap luka, da n setelah 2-3 hari luka akan mengering dan kira-kira selama 5 hari luka dapat sembuh[20]. Daunnya sendiri juga dapat mencegah pendarahan bagi kulit yang terluka. Sangat banyak yang menggunakan daun ini untuk proses pengobatan luka pada kulit. Disamping mudah dalam prosesnya dan praktis dalam memanfaatkannya.[21][22]

\section{METODE}


Saat melakukan penelitian pastinya sebelum itu pasti membutuhkan alat dan bahan. Pada saat melakukan uji coba terhadap getah daun bitadin ini peralatan dan bahannya antara lain:

1. Alat

- Pisau/gunting

2. Bahan

- Tumbuhan bitadin

Perosedur kerja

1. Penyiapan sampel[23]

Tumbuhan ini di ambil dari daerah kabupaten Pasaman Barat, simpng empat, jambak jalur 5 barat.

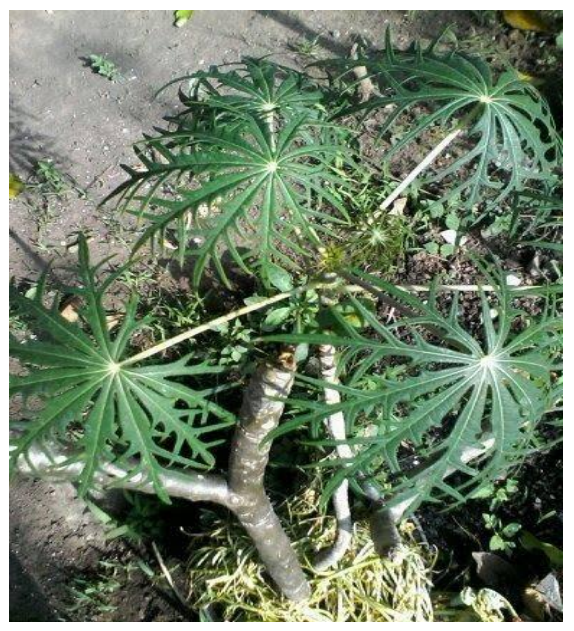

Setelah tubuhan sudah di temukan maka langkah selanjutnya yang kita lakukan iyalah untuk melakukan pengobatan luka kita mengambil ranting-ranting dari tumbuhan bitadin tersebut dengan cara memotongnya dengan pisau atau gunting. Sebenarnya bisa lansung tanpa menggunakan alat tapi agar pengambilan sampel baik maka di gunakan alat.

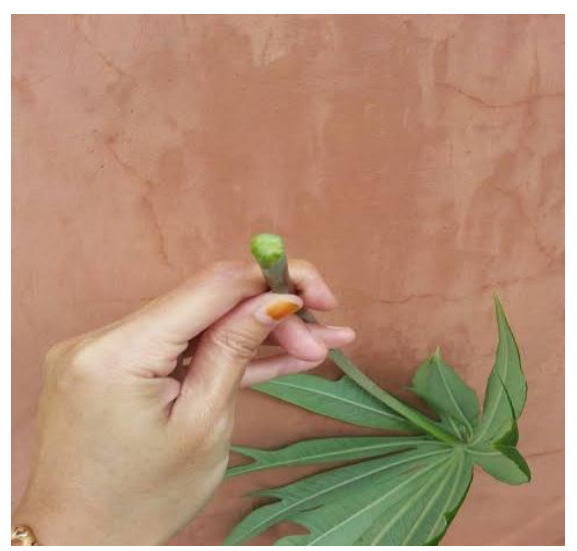

2. Pengambilan getah 
Setelah smpel diambil. Seperti gambar di atas, saat sampel telah lepas dari batangnya beberapa saat dari ujung sampel akan mengeluarkan cairan yang mana cairan itu merupkan getah dari tumbuhan bitadin.

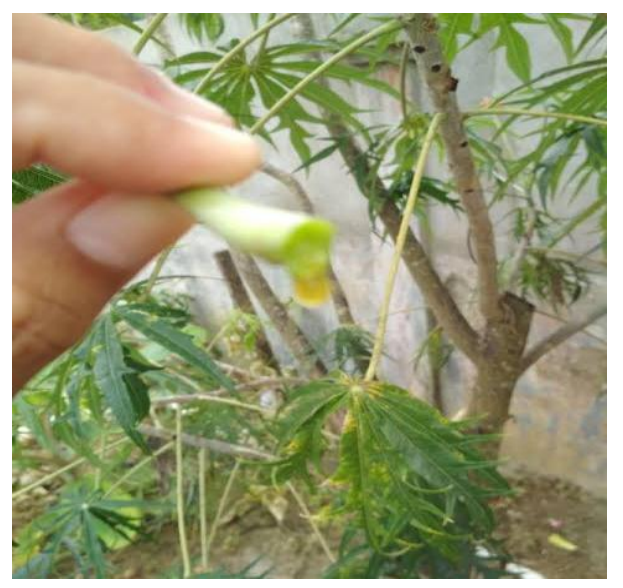

Maka cairan yang keluar dari sampel yg d ambil tadi keluar, cairan berwarna kuning seperti yang terlihat di atas.

\section{Pengujian sampel}

Setelah tahap pengambilan bahan dilakukan selanjutnya getah yang dihasilkan dari proses pengambilan sampel tadi di berikan segera ke kulit yang terkena luka.jika lama untuk di berikan getah akan menumpuk kemudian akan menetes dan terbuang untuk itu saat sampel tlah mengeluarkan getah lansung di beri kepada kult yang terkena luka.

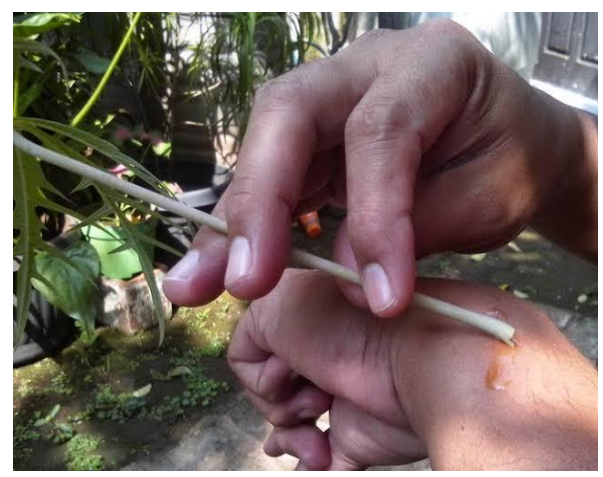


Metode ini dapat di buat secara diagram alir:

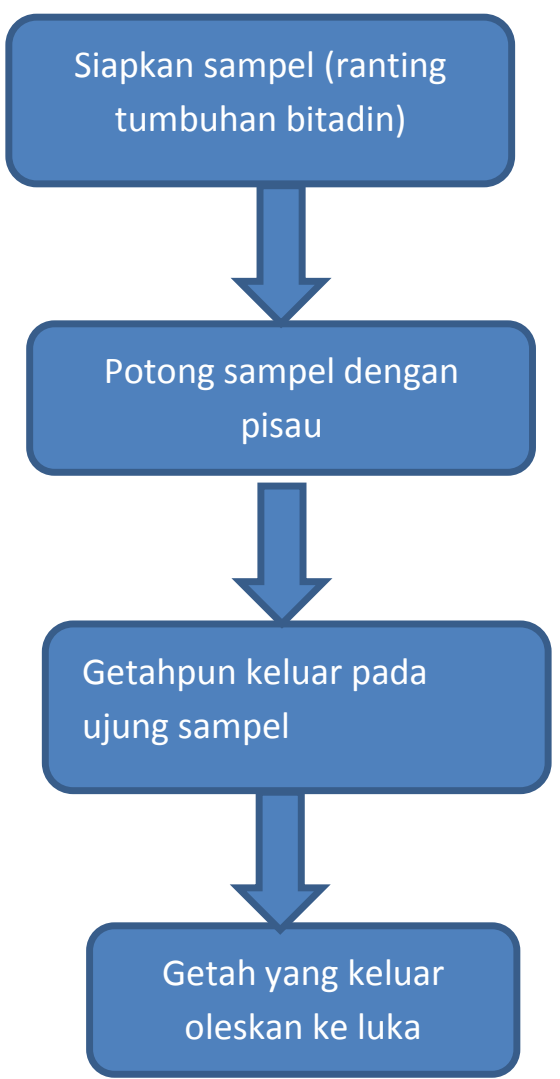

\section{HASIL PERCOBAAN}

pada saat penggunaan getah ini terhadap yang mengalami luka ringan siklusnya bisa dilihat pada tabel untuk proses penyembuhannya.

\begin{tabular}{|l|l|}
\hline Hari & persen penyembuhan \\
\hline 1 & $20 \%$ \\
\hline 2 & $40 \%$ \\
\hline 3 & $60 \%$ \\
\hline 4 & $80 \%$ \\
\hline 5 & $100 \%$ \\
\hline
\end{tabular}




\section{PEMBAHASAN}

Pada pembahasan kali ini kita akan melakukan pengujian sampel bahan alam untuk sebagai alat transportasi dalam menyembuhkan luka[23]. Tujuan dari pengujian ini iyalah untuk mengetahui kandungan apa saja yang terkandung pada sampel yang akan di uji sebagai objek dalam penyembuhan luka dan untuk mengetahui langkahlangkah dalam penggunaan bahan alam sebagai alat transportasi dalam penyembuhan[24][25].

Pada percobaan kali ini kami menggunakan tanaman tumbuhan bitadin yang mempunyai nama latin jatropha multifida L[26]. Yang mana yang digunakan dari tumbuhan ini iyalah getahnya. Maka untuk itu objek yang kami uji dari tumbuhan itu iyalah getahnya.[27]

Pada tahapan pebuatan sampel di karenakan tumbuhan ini sangat banyak di jumpai untuk proses menemukan serta pembuatannya kami tidak mengalami kendala[28]. langkah awal yang kami lakukan iyalah mencari tumbuhan bitadin, setelah di temukan lankah selanjutnya memotong cabang dari tumbuhan bitadin cukup 1 ranting saja, selepas di ambil rantingnya,ranting akan mengeluarkan getah kemudian dari getah yang di hasilkan lansung di berikan terhadap kulit yang mengalami luka.[29][30]

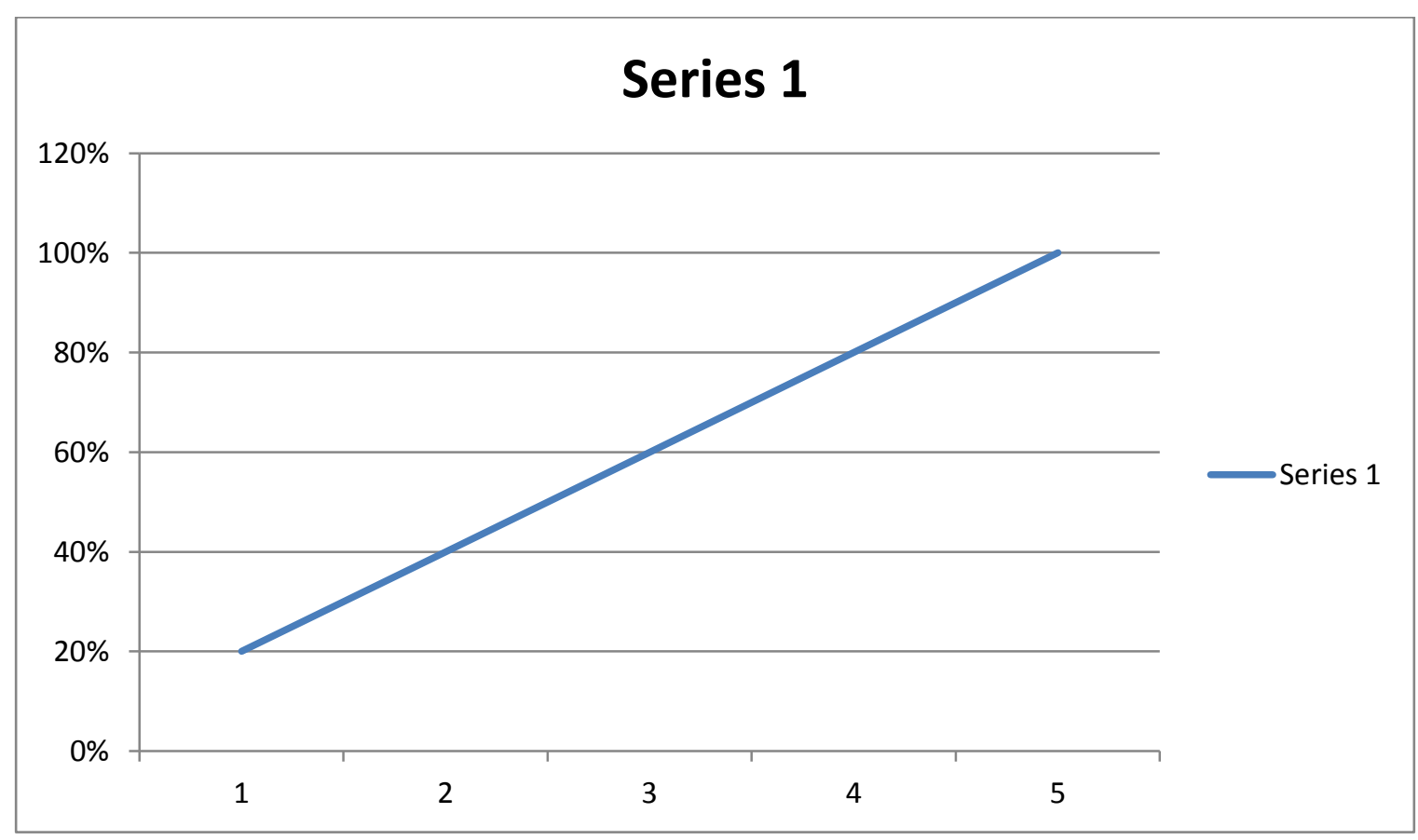


Pada grafik di atas dapat dilihat pada saat pemberian getah daun bitadin kepada kulit yang terluka :

- pada hari pertama 20\% kulit dalam proses adaptasi dengan getah dari daun bitadin,

pada tahap ini saat pemberian getah kulit akan terasa perih beberapa saat, kemudian perih pun hilang, [31]

- pada hari kedua sudah muncul tanda-tanda kulit mulai dalam tahap penyembuhan

- pada hari ketiga kulit yang terkena luka yang d beri getah akan berwarna hitam akan tetapi ini belum kering seutuhnya,

- pada hari keempat kulit warna hitam mulai mengeras dan ada tanda- tanda akan ganti kulit, dan

- pada hari ke 5 kulit yang terkena luka ganti kulit dan sembuh.[32][33]

Getah daun bitadin ini diduga kandungannya iyalah antara lain saponin, alkohol,tanin,glikosa,flavonoid,fenol dan lain-lain. Sehingga dari kandungan inilah getah dari daun bitadin itu dapat menyembuhkan luka pada kulit.[34][35]

\section{KESIMPULAN}

Dapat disimpulkan bahwa getah daun bitadin bermanfaat untuk menyembuhkan luka karena mengandung saponin,fenol,tanin dan lain lain,Penyembuhan luka ini berlansung (1-5) hari.

\section{REFERENSI}

[1]Zainul, R. (2018, August 16). Effect of Temperature and Particle Motion against the ability of $\mathrm{ZnO}$ Semiconductor Photocatalyst in Humic Acid. https://doi.org/10.31227/osf.io/wnygb

[2]Liza, Y. M., Yasin, R. C., Maidani, S. S., \& Zainul, R. (2018, October 9). SOL GEL : PRINCIPLE AND TECHNIQUE (A REVIEW). https://doi.org/10.31227/osf.io/2cuh8

[3]Zainul, R. (2018, August 16). Determination of the half-life and the quantum yield of $\mathrm{ZnO}$ semiconductor photocatalyst in humic acid. https://doi.org/10.31227/osf.io/e8a9x

[4]Febriani, S. S., Yolanda, T., Arianti, V. A., \& Zainul, R. (2018, October 12). A Review Solid Stated : Principles and Methode. https://doi.org/10.31227/osf.io/7us4x

[5]Zainul, R. (2018, August 16). Design and Modification of Copper Oxide Electrodes for Improving Conversion Coefficient Indoors Lights (PV-Cell) Photocells. https://doi.org/10.31227/osf.io/pgn84 
[6]Putri, D. F., Ritonga, H. M., Murdiati, V., \& Zainul, R. (2018, October 15). A REVIEW WHAT IS HYDROTHERMAL ?. https://doi.org/10.31227/osf.io/dm56c

[7]Zainul, R., \& Prima, C. B. (2018, November 11). Desain Geometri Sel PV. https://doi.org/10.31227/osf.io/7n8t4

[8]Guci, S. R. F., Zainul, R., \& Azhar, M. (2018, September 19). PENGEMBANGAN MEDIA PEMBELAJARAN BERBASIS TIGA LEVEL REPRESENTASI MENGGUNAKAN PREZI PADA MATERI KESETIMBANGAN KIMIA KELAS XI SMA/MA. https://doi.org/10.31227/osf.io/n7jkf

[9]Zainul, R. (2018, August 16). DISAIN, METODE DAN PENGGUNAAN SOFTWARE PEMBELAJARAN KIMIA BERBASIS IT UNTUK AKTIVITAS KELAS DAN LABORATORIUM BERBASIS INKUIRI TERBIMBING. https://doi.org/10.31227/osf.io/psf5t

[10]Jumalia, R., \& Zainul, R. (2019, February 3). Natrium Karbonat : Termodinamika dan Transport Ion. https://doi.org/10.31227/osf.io/y2vq9

[11]HAYATI. March 2012. Journal of Biosciences. Vol. 19 No. 1.DOI: 10.4308/hjb.19.1.49

[12] Nurjannah*), Achmad Roesyadi dan Danawati Hari Prajitno. Juni 2010. KONVERSI KATALITIK MINYAK SAWIT UNTUK MENGHASILKAN BIOFUEL MENGGUNAKAN SILIKA ALUMINA DAN HZSM-5 SINTESIS. Vol. 13 No. 1

[13]Ummu Mukaromah1), Sri Hetty Susetyorini2), Siti Aminah. 2010. KADAR VITAMIN C, MUTU FISIK, pH DAN MUTU ORGANOLEPTIKSIRUP ROSELLA (Hibiscus Sabdariffa, L) BERDASARKAN CARA EKSTRAKSI. Vol. 01 No. 01

[14]Dewa Gede Katja1, Edi Suryanto1 dan Frenly Wehantouw . 2009. POTENSI DAUN ALPUKAT (Persea Americana Mill) SEBAGAI SUMBER ANTIOKSIDAN ALAMI. Vol. 2, No. 1

[15]Prayitno. 2007. KAJIAN KINETIKA KIMIA MODEL MATEMATIK REDUKSI KADMIUMMELALUI LAJU REAKSI, KONSTANTE DAN ORDE REAKSI DALAM PROSESELEKTROKIMIA. Vol. X, No. 1

[16]Endang Triwahyuni Maharani*, Ana Hidayati Mukaromah**, Jatmiko Susilo***.2012.ANALISIS KALIUM DAN PROSENTASE DAYA LARUT CALSIUM OKSALAT OLEH KALIUM DALAM AIR TEH DAUN SUKUN (Artocarpus altilis).Vol. 01 No. 01

[17]Hartiniati.2006. HIDROKONVERSI KATALITIK RESIDU MINYAK BUMI: PENGARUH TEMPERATUR DAN WAKTU REAKSI. Vol. 10 No. 2 
[18] Evy Damayanthi1*, Lilik Kustiyah1, Mahani Khalid1, dan Henry Farizal. 2010. AKTIVITAS ANTIOKSIDAN BEKATUL LEBIH TINGGI DARIPADA JUS TOMAT DANPENURUNAN AKTIVITAS ANTIOKSIDAN SERUM SETELAHINTERVENSI MINUMAN KAYA ANTIOKSIDAN. Vol. 5 No (3).

[19]Enjarlis1,2), S. Bismo1), Slamet1) dan Roekmijatik.2006. STUDI PENDAHULUAN OZONASI (KATALITIK DAN NON KATALITIK) LIMBAH CAIR KARBOFURAN. Vol. 10 No. 2.

[20]Endang Triwahyuni Maharani*, Ana Hidayati Mukaromah**, Jatmiko Susilo***.2012. ANALISIS KALIUM DAN PROSENTASE DAYA LARUT CALSIUM OKSALAT OLEH KALIUM DALAM AIR TEH DAUN SUKUN (Artocarpus altilis).Vol 01, No 01.

[21]Rizki Saputra, M. and Sumarmin, R. (2018) "PENGARUH EKSTRAK DAUN SIRIH MERAH (Piper crocatum Ruiz \& Pav.) TERHADAP GLUKOSA DARAH MENCIT (Mus musculus L.) JANTAN YANG DIINDUKSI SUKROSA”, EKSAKTA: Berkala Ilmiah Bidang MIPA, 19(1), pp. 43-55. doi: 10.24036/eksakta/vol19-iss 1/124.

[22]Prabowo, H. (2018) "PENYELIDIKAN KELAYAKAN KIMIA DAN PENYEBARAN CADANGAN PASIR BESI DAERAH TIKU KABUPATEN AGAM UNTUK BAHAN BAKU SEMEN PADA PT. SEMEN PADANG”, EKSAKTA: Berkala Ilmiah Bidang MIPA, 19(1), pp. 39-42. doi: 10.24036/eksakta/vol19-iss1/121.

[23]Enjelina, W., Mansyurdin, M. and Meideliza, T. (2018) "Analysis of Nepenthes Hybrids in Bukik Taratak West Sumatra by RAPD Technique”,EKSAKTA: Berkala Ilmiah Bidang MIPA, 19(2), pp. 12-20. doi: 10.24036/eksakta/vol19-iss2/137.

[24]Badrulfalah, B., Irianingsih, I. and Joebaedi, K. (2018) "Some Operations on Mixed Monotone Operator in Banach Spaces”,EKSAKTA: Berkala Ilmiah Bidang MIPA, 19(2), pp. 57-61. doi: 10.24036/eksakta/vol19-iss2/150.

[25]Chatri, M., Mansyurdin, M., Bakhtiar, A. and Adnadi, P. (2017) "PERBANDINGAN KOMPONEN MINYAK ATSIRI ANTARA DAUN MUDA DAN DAUN DEWASA PADA HYPTIS SUAVEOLENS (L.)POIT”,EKSAKTA: Berkala Ilmiah Bidang MIPA, 18(02), pp. 1-12. doi: 10.24036/eksakta/vol18-iss02/41.

[26]Sari, A. (2017) "POTENSI ANTIOKSIDAN ALAMI PADA EKSTRAK DAUN JAMBLANG (Syzigium cumini (L.) Skeels)",EKSAKTA: Berkala Ilmiah Bidang MIPA, 18(02), pp. 107-112. doi: 10.24036/eksakta/vol18-iss02/61.

[27]Susilaningrum, D. (2017) "PEMODELAN REGRESI LOGISTIK PADA FAKTOR YANG MEMPENGARUHI PHBS PADA RUMAH TANGGA PENDERITA TBC DI PESISIR SURABAYA”, EKSAKTA: Berkala Ilmiah Bidang MIPA, 18(02), pp. 121-128. doi: 10.24036/eksakta/vol18-iss02/65. 
[28]Mulia, M. (2017) "ISOLASI KUMARIN DARI KULIT BUAH LIMAU SUNDAI (Citrus nobilis Lour)", EKSAKTA: Berkala Ilmiah Bidang MIPA, 18(02), pp. 137-145. doi: 10.24036/eksakta/vol18-iss02/70.

[29]Tutuarima, T. (2017) "SIFAT FISIK DAN KIMIA MARMALADE JERUK KALAMANSI (Citrus microcarpa) : KAJIAN KONSENTRASI PEKTIN DAN SUKROSA Physical and Chemical Properties of Marmalade Citrus of Calamondin (Citrus microcarpa) : Study of Pectin and Sucrose Concentrations", EKSAKTA: Berkala Ilmiah Bidang MIPA, 18(02), pp. 164-172. doi: 10.24036/eksakta/vol18-iss02/73.

[30]Setianto, S. (2017) “ANALISA KUANTITATIF CAMPURAN SENYAWA OKSIDA SEBAGAI DASAR IDENTIFIKASI KANDUNGAN BAHAN SUMBER DAYA ALAM Studi Kasus : Kandungan Mineral pada Pasir Besi di Pesisir Pantai Selatan, Jawa Barat",EKSAKTA: Berkala Ilmiah Bidang MIPA, 18(02), pp. 173-177. doi: 10.24036/eksakta/vol18-iss02/74.

[31]Iskandar, I., Horiza, H. and Fauzi, N. (2017) "EFEKTIVITAS BUBUK BIJI PEPAYA (Carica Papaya Linnaeaus) SEBAGAI LARVASIDA ALAMI TERHADAP KEMATIAN LARVA AEDES AEGYPTY TAHUN 2015",EKSAKTA: Berkala Ilmiah Bidang MIPA, 18(01), pp. 12-18. doi: 10.24036/eksakta/vol18-iss01/12.

[32]Horiza, H., Azhar, M. and Efendi, J. (2017) "EKSTRAKSI DAN KARAKTERISASI INULIN DARI UMBI DAHLIA (Dahlia sp.L) SEGAR DAN DISIMPAN”, EKSAKTA: Berkala Ilmiah Bidang MIPA, 18(01), pp. 31-39. doi: 10.24036/eksakta/vol18-iss01/14.

[33]Ramli, R., Jonuarti, R. and Hartono, A. (2017) "ANALISIS STRUKTUR NANO DARI LAPISAN TIPIS COBALT FERRITE YANG DIPREPARASI DENGAN METODE SPUTTERING",EKSAKTA: Berkala Ilmiah Bidang MIPA, 18(01), pp. 46-53. doi: 10.24036/eksakta/vol18-iss01/16.

[34]Suryelita, S., Etika, S. B. and Kurnia, N. S. (2017) "ISOLASI DAN KARAKTERISASI SENYAWA STEROID DARI DAUN CEMARA NATAL (Cupressus funebris End1.)",EKSAKTA: Berkala Ilmiah Bidang MIPA, 18(01), pp. 86-94. doi: 10.24036/eksakta/vol18-iss01/23.

[35]Iryani, I., Iswendi, I. and Katrina, I. T. (2017) "UJI AKTIVITAS ANTI DIABETES MELLITUS SENYAWA METABOLIT SEKUNDER FRAKSI AIR DARI BERAS KETAN HITAM ( Oryza satival. Var glutinosa) PADA MENCIT PUTIH", EKSAKTA: Berkala Ilmiah Bidang MIPA, 18(01), pp. 54-60. doi: 10.24036/eksakta/vol18-iss01/17. 
